\title{
STIGMATIZATION OF PERSONS INFECTED WITH HEPATITIS B VIRUS AND THE ROLE OF SOCIAL WORKERS IN RIVERS STATE, NIGERIA
}

\author{
Gobo, Blessing Ngowari \\ Department of Social Work \\ University of Nigeria, Nsukka, Enugu State, \\ Nigeria \\ Egbuchu, Samuel A. \\ Department of Psychology \\ Rivers State University, Nigeria.
}

\begin{abstract}
Hepatitis B virus (HBV) which is slowly yet evidently taking the lives of able bodied men and women in the society can be managed if proper education and enlightenment strategies are put in place to curb the infection and help those already infected. Variety of factors influence people's reaction towards those infected with the virus this is evident in the high level of stigmatization experienced by those infected with HBV. The study was carried out in Okrika Local Government Area of Rivers state. Data was gotten from a qualitative study of sixty persons (Four Focused Group Discussions [FGDs] involving forty persons and twenty In-depth interviews). The study identified factors such as education, traditions and archaic practices, religion and income as having a great influence on the stigma associated with persons infected with $\mathrm{HBV}$. Participants identified that these stigmas pose great threat to the health and survival of those infected. This finding strongly suggests that stigmatization against HBV infected persons should be put to an end. The need for the inclusion of social work related services in $\mathrm{HBV}$ care was also recommended.
\end{abstract}

Keywords- Stigmatization, Hepatitis B Virus (HBV), social work, Nigeria

\section{INTRODUCTION}

Hepatitis B virus (HBV) which is slowly yet evidently taking the lives of able bodied men and women in the society can be managed if proper education and enlightenment strategies are put in

\author{
Onalu, Chinyere E. \\ Department of Social Work \\ University of Nigeria, Nsukka, Enugu State, \\ Nigeria \\ Chukwu, Ngozi C. \\ Department of Social Work \\ University of Nigeria, Nsukka, Enugu State, \\ Nigeria
}

place to curb the infection and help those already infected. The prevalence of HBV disease in Nigeria as a whole is not known although the country has long been considered to be among the highly endemic countries of sub-Saharan Africa [34]. Hepatitis B infection is caused by the hepatitis B virus (HBV), an enveloped DNA virus that infects the liver, causing hepatocellular necrosis and inflammation [35]. The world Health Organization in 2014 reported that HBV caused over one million deaths yearly with about $5-15 \%$ adults chronically infected with this virus in the sub-Saharan African region. According to a 2015 World Health Organisation report, HBV infection can be acute or chronic. The linked illness ranges in severity from asymptomatic to symptomatic, progressive disease. Acute HBV infection is characterized by the presence of HBsAg and immunoglobulin M (IgM) antibody to the core antigen, $\mathrm{HBcAg}$. During the initial phase of infection, patients are also seropositive for hepatitis B e antigen $(\mathrm{HBeAg})$. $\mathrm{HBeAg}$ is usually a marker of high levels of replication of the virus. The presence of $\mathrm{HBeAg}$ indicates that the blood and body fluids of the infected individual are highly infectious while Chronic Hepatitis B (CHB) is defined by persistence of hepatitis B surface antigen (HBsAg) for six months and beyond is a key health problem for the public [33]. Internationally, it has been observed that $\mathrm{HBV}$ is a key universal health infectious disease causing harm to the liver. Approximately, over 2 billion people have been infected with Hepatitis B virus and an estimated 350 million people are chronic carriers of the virus while about 1 million people die yearly from hepatitis B and its complications $[24,32$, 


\section{International Journal of Engineering Applied Sciences and Technology, 2019 \\ Vol. 4, Issue 3, ISSN No. 2455-2143, Pages 48-54}

Published Online July 2019 in IJEAST (http://www.ijeast.com)

18]. Hepatitis B virus (HBV) spreads through the blood and other bodily fluids during sexual and nonsexual contacts [26]. HBV can be transmitted through semen, vaginal fluids, blood, and it can be transferred from a mother to her child during delivery. Also, sharing needles, unsafe tattoo techniques, sharing of personal items like razors, tooth brushes and having unprotected sex increase the risk of HBV [23, 1, 10]. Furthermore Wilkins et al. [2010] revealed that the symptoms of HBV infection include: fatigue, poor appetite, nausea, vomiting, abdominal pain, low-grade fever, jaundice and dark urine. Clinically, the signs are liver tenderness, hepatomegaly and splenomegaly.

It is disheartening to note that many people infected with HBV do not know that they have the virus. This is because HBV symptoms can take two to six months to appear and only about fifty percent of people develop the symptoms, during this time; they can spread the infection to others [17]. Unfortunately, HBV is symptomless. An infected person can spread the virus without even being aware [10]. The signs and symptoms associated with HBV infection are imprecise and are characterized by furtive inception of depression, jaundice, extreme fatigue, anorexia, nausea, vomiting, right upper quadrant abdominal pain, fever, headache, myalgia, skin rashes, arthralgia/arthritis, dark urine and acute liver failure which leads to death [34, 19]. In a bid to educate people on HBV WHO set aside every July 28 as world HBV day to increase awareness and understanding of viral hepatitis [31]. Equally in 2012, a pentavalent vaccine comprising diphtheria, tetanus, pertussis, HBV, and Haemophilus influenza type B was introduced [15]. Despite efforts put in place, ignorance and no knowledge of HBV infection is still the major reason for the prevalence of HBV [28]. Persons infected with hepatitis B are largely stigmatized due to ignorance about the disease. In some communities, people with hepatitis $B$ infection do not disclose their status because of the fear of being shunned. Fear and ignorance have cost people their jobs, friendships and relationships [22]. Historically, social discrimination against patients with infectious diseases such leprosy, tuberculosis and HIV exist. Several scholars have expounded that people living with infectious diseases frequently are marginalized and experience considerable stigmatization [20, 22]. Additionally, people infected with Hepatitis B have been described as modern-day "lepers" or "AIDS patients", this has made individuals with HBV as well as their families been shamed about having HBV [35, 22]. Stigmatization associated with the virus is the reason why a significant number of people have refused testing and vaccination. Social workers are needed to curb the phenomenon. Social workers are practically involved with providing support for people especially those marginalized and stigmatized due to health challenges such as HBV [9]. Social workers provide relevant information and facilitate testing for individuals. Social workers have transferable skills and capacities that can help people infected with $\mathrm{HBV}$, their various involvement and experiences on the job helps in reducing the stigma associated with persons infected with the virus [13].

Additionally, the Protection Motivation Theory (PMT) developed by Rogers (1975) was adopted for the study's theoretical framework. PMT argues that the protection motivation decision is made after people utilize information to assess a threat and the ability to deal with that threat. PMT is one model that explains why people engage in unhealthy practices such as: sharing personal/sharp object and engaging in multiple sexual partners and offers suggestions for changing those behaviours such as: maintaining a healthy sex life, non-sharing of sharp/personal objects. The theory is educational and motivational. So an individual will use stigmatization as a tool to not get infected with HBV.

Various studies have been carried out on HBV but very few studies exist on level of stigmatization faced by persons infected with HBV. Gboeze et al. (2015) carried out a cross-sectional study on the knowledge and awareness of Hepatitis B Virus Infection among Pregnant Women, Olorunfemi et al. (2017) carried out a study on seroprevalence and knowledge of Hepatitis B and C among health workers in the specialist hospital, in Abakalili. Also, Eredoro and Egbochuku in 2017 carried out a research on the level of awareness and opinions about Hepatitis B among secondary school teachers in Irepodun Local Government Area of Kwara State, in the Southwest. These studies and many more mainly focused on knowledge of $\mathrm{HBV}$ and not on the increased rate of stigmatization, hence the need for this study. This study investigated the level of stigmatization of existing as a result of HBV infection. We conducted four focused group discussions, two with people who are infected with the virus and two with those who had knowledge of HBV as a result of knowing people who had died from the virus. The objectives of this study were to: find out their knowledge of HBV, indicate the factors promoting stigmatization, find out the roles social workers can play in putting an end to HBV stigmatization and finally suggest the way forward. 


\section{STUDY DESIGN, STUDY AREA, SAMPLING, PARTICIPANTS AND RECRUITMENT}

Participants within the age intervals of $18-65$ years, who reside in Okrika Local Government Areas, were qualitatively studied for ten months (April 2018 February 2019). The instrument utilized for this study was drawn from the questionnaires of Olayinka et al., (2016) and Okonkwo et al. (2017) although we modified it to suit our study.

Community leaders and Medical personnel at the various community health centres in the study area provided information of others infected and those who had knowledge and experience of the HBV. Out of the data gotten, forty (40) men and women were purposively sampled for the four sessions of the focused group discussion and another twenty men and women who had in-depth knowledge of HBV and stigmatization were utilized for the IDI. All participants were given written consent before being used for the FGDs and IDIs.

\section{Instruments}

A semi-structured topic guide developed from literature review was the guide of this study. The questions followed thus:

\section{Focus Group Schedule}

- What's your knowledge of HBV?

- What are the various factors increasing the level of stigmatization existing among people infected with $\mathrm{HBV}$

- What is the mode of transmission and cure for HBV?

- What role can social workers play in bringing an end to the stigma and how can they improve the health and livelihood of people infected with HBV?

In-depth interview guide

- Are you aware of HBV?

- Are you infected with HBV?

- Do you know someone infected with HBV?

- Have you been stigmatized as a result of HBV?

- Do you know someone who has been stigmatized with HBV?

- What do you think is the way forward?

Analysis
The responses gotten were written down in verbatim and they were anonymous to promote confidentiality. The interviews were electronically recorded and conducted through an interpreter. The questions were asked in English language, it was then interpreted in "kirike" language and the responses were then interpreted into English language. The length of the discussion ranged from 40 to 70 minutes. We followed the stages of Braun and Clarke (2006) for the data analysis. The transcripts were exhaustively coded by hand and then entered into NVivo 10 (QSR International Pty Ltd., VIC, Australia). Themes were identified and refined through discussion with the team.

\section{RESULTS}

The socio-demographic characteristics of the sixty respondents are shown in Table 1. They ranged from $18-60$ years and above.

\section{A. Knowledge of Hepatitis B}

Majority of the respondents mentioned that they were aware of HBV. HBV according to them is an infection that affects people who are ignorant of it. HBV is very deadly, it causes serious side effect to the body and even leads to cancer. Below are responses in terms of knowledge of $\mathrm{HBV}$.

An in-depth interview with a 42 year old man revealed thus:

The virus Hepatitis $B$ is an incurable virus that has an effect on any person who contacts it. The symptoms of $H B V$ are not easily noticed, so they can ignorantly infect others with the virus. It is until $H B V$ develops to serious problems like cancer, that the carrier may notice some signs. By this time most persons infected with the virus die since the infection cannot be cured yet (IDI, 42 year old Nurse).

Another respondent opined thus:

Before today I have heard of HBV. I know it is very deadly and it's a time-bomb waiting to explode. $H B V$ kill the carrier silently but speedily. Just like HIV/AIDs, HBV has no cure when it affects the liver it damages the person completely. You see the person looking pale and skinny with his/her eyes yellow. HBV 100 times worst than HIV/AIDs (FGD with a woman aged 35 years).

Furthermore, various signs and symptoms were outlined. Respondents mentioned the yellowing of the eyes (jaundice), paleness, fatigue etceteras. 


\section{International Journal of Engineering Applied Sciences and Technology, 2019 Vol. 4, Issue 3, ISSN No. 2455-2143, Pages 48-54 \\ Published Online July 2019 in IJEAST (http://www.ijeast.com)}

I have had a dear friend who suffered from $H B V$. The signs I saw him portray were: depression, jaundice, fatigue/tiredness, anorexia/lack of appetite, vomiting, abdominal pain, back pain, fever, headache, rashes and acute liver failure (IDI with a 55 year old civil servant).

\section{B. Stigmatization from $\mathrm{HBV}$ infection}

The FGD conducted for patients infected with HBV revealed that stigmatization is a serious problem that needs to be addressed in other to avoid most infected persons committing suicide. Below are the responses gotten:

A female participant infected with HBV disclosed that:

I have been bad mouthed and called all sort of names because I am infected with HBV. I have been outcasted in the society; nobody wants to associate with me. They keep saying it is my sins that have caught up with me. I agree that I made a mistake but should I keep suffering like this. If I get to the market nobody wants to collect my money in exchange for their goods. A lot of women in the market think I will infect them through exchanging pleasantries. These name calling and stigmatization makes me contemplate suicide. Most persons have refused to go for the screening to avoid being stigmatized if found positive to $H B V$ (45 years, FGD with women infected with $H B V)$.

A 62 year old man said:

I got infected with this virus ignorantly, during my childhood my parents had no knowledge of vaccination that would have prevented me from contacting this infection. Younger persons of today are at greater advantage because the government and medical personnel have made available childhood vaccinations. Elderly persons like us only have to manage our lives and all that comes with it (IDI with a 62 year old man).

A 32 year old woman narrated her experience on the stigma associated with HBV, she lost her father to the virus and she had this to say:

People don't care or think about how HBV is transmitted, most people are afraid to even touch someone who has Hepatitis B. When my dad was sick the very few people who knew about it refused visiting for fear of contracting the virus, even relating to us his children on the road was a challenging as they felt we must have contracted the virus in the course of taking care of our sick dad. People don't even want to get tested, because Hepatitis B treatment is either not available or costs too much money in this part of the country (FGD; 32 year old woman).

An issue of people infected with Hepatitis B been stigmatized and discriminated in their work-place was raised. A private company worker aged 45 years old narrated how her colleague lost his job because of HBV. She opined thus:

I had a colleague who was married with four children. When the company found out from the company's private hospital where my colleague received his treatment that he had hepatitis $B$ he was immediately fired and left to carter for his medical needs alone. He was isolated and left to die by the company he once worked for. I also know of a woman who died in 2009 from negligence by her company, they sacked her immediately the medical report proved that she had $H B V$. All of this discrimination is unethical, unnecessary and a violation of one's human rights. From my knowledge of Hepatitis B, it is not transmitted through casual contact; this stigma only persists because of the high level of ignorance existing in this state. To avoid this, government must enlighten the people on what $H B V$ really is (IDI with a 45 year old woman).

A 19 years old girl narrated thus:

My relative found out that I had $H B V$ so they asked me to never come and visit them; they insisted that I was going to infect their children with the virus. I felt disheartened because if my own family can rebuff me what else do I expect from the society at large (FGD, 19 years old).

A nurse who also participated in the session with persons not infected revealed how five boys of ages 14-35 years contracted the virus.

Just recently, a fellow nurse working in at the health centre told me of how five boys contracted the virus. These boys are from a cult group they pierced their hands and dropped their blood into the cup, then they drank their bloods and unfortunately one of them blood was infected with $\mathrm{HBV}$ and that was how the remaining four persons contacted the virus. It was during a free screening test that among the entire twenty-three cult members only five of them were infected (Nurse aged 40 years). 


\section{Mode of transmission, cure and vaccination}

Issues on the mode of transmission of the virus were raised and a 59 year old man disclosed thus:

I know of a child who got the virus through her mother. When she was pregnant she didn't utilize proper medical care; a skilled birth attendant conducted the delivery. But after we saw how the child's eyes coloured and the baby was just getting pale and pale we decided to go to the hospital and that was how we found out the child had Hepatitis (IDI; 59 year old woman).

A 44 year old nurse who participated in the Focus Group discussion organized for persons not infected with HBV opined thus:

Hepatitis $B$ is not curable but can be prevented in infants especially through vaccination. Also, before one gets infected with the virus it is good to go for the vaccine, this will make an individual immune to the virus (FGD; 44 years old).

\section{DISCUSSIONS}

The study sought to investigate the level of stigmatization of persons infected with hepatitis B virus and the role of social workers in Rivers state, Nigeria. Findings from this study will contribute to policies and programmes seeking to reduce ignorance of $\mathrm{HBV}$, causes of $\mathrm{HBV}$, and stigmatization of HBV persons. Stigmatization has affected the economic, educational, relationships and social aspects of those infected with the virus. Most persons infected with HBV often times consider suicide due to the harsh treatment gotten from the society. The study revealed that the knowledge of $\mathrm{HBV}$ is high, people are aware of what HBV and the effect of HBV. This finding disagrees with that of Afihene et al. (2015) according to them there is paucity of information on knowledge, attitude and practice (KAP) concerning HBV among HCWs, especially among developing countries like Ghana. HBV is deadly and affects one through contact with an infected person. It is also important to note here that the signs do not show up immediately but eventually it occurs and kills the person. Congruently, Davis (2018) also revealed that HBV is symptomless; an infected person can spread the virus without even being aware. The virus affects the liver and eyes and even makes the infected person loss a lot of weight. Knowledge and awareness of HBV helps in the proper prevention and management of the infection. According to Gboeze et al. (2015), knowledge and awareness prevents ignorance and stigmatization of associated with HBV. Participants who have revealed their knowledge of the virus can help those who are still ignorant of HBV. Various experiences were narrated as regards the stigma associated with HBV. The study found that people infected with the virus experiences name callings and these names tend to devalue and affect their self esteem. Also issues of people keeping their distance and breaking all forms of ties were identified. Children and relatives of those infected with the virus also revealed that they have been stigmatized by the society who should care. Most persons have lost their jobs after been tested positive to HBV and after the job loss they lacked the where withal to maintain their lives. The study also found that one can contact the infection through Mother-to-child-transmission. Musa et al. (2015) identified it as the main route of HBV transmission in Nigeria. Therefore, infant immunization against HBV drastically reduces the prevalence rate of HBV [6]. Immunization/vaccination is the best for HBV infection prevention [22]. Introducing hepatitis B vaccines into primary health care services will improve the knowledge of $\mathrm{HBV}$ as well as prevent its spread even at the grass root level. It will also give room to improving its accessibility and availability for everyone.

\section{SUGGESTIONS/LIMITATIONS OF THE STUDY}

Suggestions from this study include enlightening and educating the masses on HBV. Doing this increases the society's awareness and sensitivity of the virus. Also, Hepatitis B prevention measures should be initiated for elderly people born before the era of universal vaccinations. Vaccines and testing services should be made free and available; carry out widespread awareness creation and serious education of the masses to expose the dangers and means of preventing HBV and finally, social workers can liaise with the right bodies to carry out these enlightenment programmes.

This study encountered several limitations. One of such was getting twenty willing participants infected with HBV was tasking. No one wanted to be associated with the virus so almost everyone denied having the virus even after medically testing positive to it. Getting people to one location at a particular time was also not an easy one. Nonetheless, this study had a different view to life and the various experiences of people. 


\section{CONCLUSION}

Our findings showed that although the knowledge of $\mathrm{HBV}$ is high, most persons are still ignorant on the mode of transmission. Individuals infected with HBV suffer from stigmatization which goes a long in affecting their self-esteem. Social work is of immense relevance in Nigeria if policies related to hepatitis $\mathrm{B}$ are to be fashioned, implemented, monitored and sustained. As policy experts, social workers must be consulted and made to be part of the policy making process and implementation.

\section{REFERENCES}

1. Abdulai M. A., Baiden F., Adjei G., and Owusu-Agyei S. (2016). Low level of Hepatitis B knowledge and awareness among pregnant women in the Kintampo North Municipality: implications for effective disease control. Ghana medical Journal, Vol. 50, No. 3, (pp.157-162).

1. Afihene M, Y., Duduyemi B. M., Tetteh H. L., and Khatib M. (2015). Knowledge, attitude and practices concerning Hepatitis B infection, among healthcare workers in Bantama, Ghana: a cross sectional study. International Journal of Community Medicine and Public Health, Vol. 2, No. 3, (pp.244-253).

2. Beasley R. P. (2009). Rocks along the road to the control of HBV and HCC. Journal of Annual Epidemiology, Vol. 19, No. 4, (pp.231-234).doi:

10.1016/j.annepidem.2009.01.017.

3. Belo A. C. (2000). Prevalence of hepatitis B virus markers in surgeons in Lagos, Nigeria. East Africa Medical Journal, Vol. 77, No. 1, (pp.283-285).

4. Bhattarai S., K. C. S., Pradhan P. M., Lama S., and Rijal, S. (2014). Hepatitis B vaccination status and needle-stick and sharps-related injuries among medical school students in Nepal: a cross-sectional study. BMC Respiratory Notes, Vol. 7, No. 1, (pp.774).

5. Braun V, and Clarke V. (2006). Using thematic analysis in psychology. Qualitative Res Psychol, Vol. 3, No. 1, (pp.77-101). doi: 10.1191/1478088706qp063oa.

6. Chan O. K., Lao T. T., Suen S. S. H. and Leung T. Y. (2012). Deficient knowledge on hepatitis b infection in pregnant women and prevalence of hepatitis b surface antigen carriage in an endemic area: A review.
Hepatitis Research and Treatment, Vol. 31, No. 7, (pp.1-8).

7. Chae H.B., and Hann H. W. (2007). Time for an active antiviral therapy for hepatitis B: An update on the management of hepatitis B virus infection. The Clinical Risk Management; Vol. 3, No. 6, (pp.05-12).

8. Chang M. H (2000). Natural history of hepatitis $\mathrm{B}$ virus infection in children. Journal of Gastroenterol Hepatol, Vol. 15, No. 1, (pp.16-19).

9. Crockett B., and Gifford S. (2004). "Eyes wide shut": Narratives of women living with HCV in Australia, Women \& Health, Vol. 39, No. 4, (pp.117-137).

10. Davis K. (2018). Everything you need to know about hepatitis B, Medical News

Today Newsletter, https://www.medicalnewstoday.com/articles 1306288.php\#treatment [Accessed 7.11.2018]

11. Demir M., and Demir C. (2012). Effect of hepatitis $\mathrm{B}$ virus infection on right and left ventricular functions, Medical Science Monitor, Vol. 18, No. 9, (pp.CR587CR591).

12. Dienstag J. L. (2008). Hepatitis B virus infection, National England of Journal Medicine, Vol. 359, No. 14, (pp.14861500).

13. Drayton J. (2013). Bodies-in-life/bodies-indeath: Social work, coronial autopsies and the bonds of identity, British Journal of Social Work, Vol. 43, No. 2, (pp.1-18).

14. Eredoro C.O, and Egbochuku O.O (2017). Awareness and Opinions about Hepatitis B among Secondary School Teachers in Irepodun Local Government Area of Kwara State, Nigeria. Health Science Journal, Vol. 11, No. 5, (pp.530).

15. GAVI (2015). Nigeria Launches Pentavalent Vaccine, http://www.gavi.org/Library/News/GAVIfeatures/2012/Nigeria-launches-pentavalentvaccine/ [ Accessed June 24, 2018].

16. Gboeze A. J., Ezeonu P. O., Onoh R. C., Ukaegbe C. I., and Nwali M. I. (2015). Knowledge and Awareness of Hepatitis B Virus Infection among Pregnant Women in Abakaliki Nigeria, Journal of Hepatitis Res, Vol. 2, No. 3, (pp. 10-29).

17. Government of Canada (2014). Hepatitis B Get the Facts: What You Need to Know, https://www.canada.ca/en/publichealth/services/surveillance/blood-safety- 


\section{International Journal of Engineering Applied Sciences and Technology, 2019 Vol. 4, Issue 3, ISSN No. 2455-2143, Pages 48-54 \\ Published Online July 2019 in IJEAST (http://www.ijeast.com)}

contribution-program/bloodbornepathogens-section/hepatitis/hepatitis-bfacts.html [ Accessed August 24, 2018].

18. Haq N., Azmi M., Akmal A., Saleem F., Farooqui M., Haseeb A., and Aljadhey H. (2013). A cross-sectional assessment of knowledge, attitude and practice among hepatitis B patients in Quetta, Pakistan, BMC Public Health, Vol. 13, No. 4, (pp.440-448).

19. Hamborsky J., and Kroger A. (2015). Epidemiology and Prevention of VaccinePreventable Diseases, E-Book: The Pink Book: Public Health Foundation.

20. Katz I. T., Ryu A. E., Onuegbu A. G., Psaros C., Weiser S. D., and Bangsberg D. R, (2013). Impact of HIV-related stigma on treatment adherence: Systematic review and meta-synthesis, Journal of International AIDS Soc, Vol. 16, No. 32, (pp.18640).

21. Kwon S. Y., and Lee C. H. (2011). Epidemiology and prevention of hepatitis $\mathrm{B}$ virus infection. The Korean Journal of Hepatology, Vol. 17, No. 2, (pp.87-95).

22. Lee H., Fawcett J., Kim D., and Yang J. H. (2016). Correlates of Hepatitis B Virusrelated Stigmatization Experienced by Asians: A Scoping Review of Literature. Asia Pacific Journal of Oncolology Nurses, Vol. 3, No. 4, (pp.324-334).

23. Mahboobi N., Porter S. R., Karayiannis P., and Alavian, S. M. (2012). Oral fluid and hepatitis A, B and C: a literature Review, Journal of oral pathology \& Medicine, Vol. 41, No. 7, (pp. 505-516).

24. Merrill R. M., and Hunter B. D. (2011). Sero-prevalence of markers for hepatitis B viral infection. International Journal of Infection and Diseases, Vol. 15, No. 2, (pp.78-121).

25. Musa B. M, Bussell S, Borodo M. M, Samaila A. A, and Femi O. L. (2015). Prevalence of hepatitis B virus infection in Nigeria, 2000-2013: A systematic review and meta-analysis. Niger, Journal of Clinical Practice, Vol. 18, 2, pp.163-167.

26. Okonkwo U. C., Ngim O. E., Osim H., Inyama M. A., Esu M., Kooffreh-Ada E., Ndoma-Egba R., and Ezedinachi E. (2017). Knowledge of hepatitis B virus infection among traders, Journal of Clinical Practice, Vol. 20, No. 4, (PP.415-420).

27. Olayinka A. T., Oyemakinde A., Balogun M. S., Ajudua A., Nguku P., Aderinola M., and Nasidi, A. (2016). Seroprevalence of Hepatitis B Infection in Nigeria: A National Survey, The American journal of tropical medicine and hygiene, Vol. 95, No. 4, (pp.902-907). doi:10.4269/ajtmh.15-0874

28. Pathoumthonga K., Khampanisonga P., Quetb F., Latthaphasavang V., Souvong V., and Buisson Y. (2014). Vaccination status, knowledge and awareness towards hepatitis $\mathrm{B}$ among students of health professions in Vientiane. Lao PDR, Vaccine, Vol. 32, No. 4, (3-9).

29. Rogers R. W. (1975). A protection motivation theory of fear appeals and attitude change. Journal of psychology, 91 (1), (pp.93-190).

30. Wilkins T., Zimmerman D., and Schade R. R. (2010). Hepatitis B: Diagnosis and Treatment, Am Family Physician, Vol. 81, No. 8, (pp.965-972).

31. WHO (2018). Hepatitis B. Factsheet.

Retrieved online@ https://www.who.int/news-room/factsheets/detail/hepatitis-b [ Accessed November 24, 2018].

32. WHO (2012). Hepatitis B Fact sheet N1204, 2012

http://www.who.int/wer/2012/wer8440.pdf4 0 [ Accessed August 24, 2018].

33. WHO (2015). Guidelines for the Prevention, Care and Treatment of Persons with Chronic Hepatitis $B$ infection. Geneva, Switzerland: World Health Organization. http://apps.who.int/iris/bitstream/10665/154 590/1/9789241549059_eng.pdf?ua=1

[Accessed March 16, 2019].

34. WHO (2014). Guidelines for the screening, care and treatment of persons with hepatitis C infection. Geneva. Available online @ https://apps.who.int/iris/bitstream/handle/10 665/154590/9789241549059_eng.pdf;jsessi onid $=$ D9A074B1110B1C0D855E065389E1 FCB5? sequence [ Accessed August 24, 2018].

35. Zickmund S, Ho EY, Masuda M, Ippolito L, and LaBrecque DR. (2003). "They treated me like a leper". Stigmatization and the quality of life of patients with hepatitis $\mathrm{C}$, Journal of Gen Intern Med, Vol. 18, No. 8, (pp.35-44). 